DOI https://doi.org/10.30525/978-9934-588-90-7-62

\title{
МОРФОЛОГІЧНА ДЕРИВАЦІЯ В ТЕРМІНОСИСТЕМІ АКАДЕМІЧНИХ ТЕРМІНІВ НІМЕЦЬКОЇ МОВИ
}

\author{
Пилипенко О. П. \\ кандидат педагогічних наук, \\ доиент кафедри іноземної філології і перекладу \\ Національний університет біоресурсів і природокористування Украйни \\ м. Київ, Украӥна
}

Українська система вищої освіти перебуває під впливом потужних трансформаційних процесів, становлення яких не обмежується сучасними тенденціями уніфікувати системи вищої освіти для інтеграції у світові сучасні реалії. На даний час існує лише кілька досліджень терміносистем галузі вищої освіти: В. І. Тузлукова розглядала стан міжнародної педагогічної термінології [5], Б. Дреслер досліджувала когнітивнодериваційний та соціокультурний аспекти академічних терміносистем російської та німецької мов [1], 3. К. Самієв зробив порівняльне дослідження таджицької та німецької терміносистем освіти [4]. Застосування синергетичного підходу в лінгвістичному аспекті дозволяє стверджувати, що схильність терміносистеми до модифікації, іiі подальша еволюція і здатність до саморегулювання не викликає сумнівів. За словами Є. В. Пономаренко, «мова здатна справлятися 3 функціональними коливаннями в своїй системі та відторгнути або змінити їх настільки, щоб вони могли вписатися в загальну систему» [3, с. 133].

Як зазначає Н. Б. Мєчковська, «при всій типологічній різноманітності мов і неповторності їх індивідуальних доль, існують всього чотири джерела нових позначень, тобто чотири шляхи або способу поповнення словника: 1) морфемна деривація; 2) семантична деривація; 3) утворення словосполучень; 4) запозичення» [2].

Морфемна деривація полягає в утворенні нових слів за допомогою власних словотворчих морфем (афіксація), словоскладанні та абревіації. За конкретним способом афіксації розглядають суфіксальний, префіксальний i суфіксально-префіксальний способи. Афіксальний спосіб утворення термінів (приєднання афіксів і префіксів) є досить продуктивним для академічної терміносистеми німецької мови. При структурному аналізі іiі монолексемних термінів розрізняють такі наступні групи: 1. префіксально-суфіксальна група: die Ausbildung освіта, die Einschulung - набір дітей-першокласників; 2. суфіксальна 
група: die Didaktik - дидактика, die Bildung - освіта, das Gymnasium гімназія, die Forschung - дослідження, das Abitur - атестат, der Lehrling учень, das Zeugnis - свідоцтво, die Klausur - письмова робота екзаменаційна робота; 3. префіксальна група: der Unterricht - заняття.

Афіксація у термінотворенні відрізняється низкою певних особливостей, специфічних для терміносистем. До них відносять як чіткість словотвірних структур, так і стійкість набору терміностворених формантів і системність їх використання. Найбільш продуктивними суфіксами у терміносистемі академічної німецької мови $є$ суфікси іменників, які означають абстрактні та конкретні поняття. Такі іменники утворюються від дієслів, іменників і прикметників. Велику роль у термінодеривації академічної сфери відіграють суфікси іноземного походження, насамперед, 3 латинської та грецької мов (-tion, -ung).

Найбільш уживаним в академічній термінології німецької мови $\epsilon$ термінологічне словосполучення 3 прикметником у функції препозитивного визначення (модель Adjektiv + Substantiv): berufliches Gymnasium - професійна гімназія; gymnasiale Oberstufe - гімназія вищого ступеня; handlungsorientierte Methoden - методи навчання, які зоріснтовані на діяльність; fächerübergreifende Regelungen міждисциплінарні настанови при навчанні.

Морфологічна деривація у академічній терміносистемі німецької мови представлена у своїх основних різновидах: афіксація, осново- та словоскладання, абревіація. Наразі тут основними способами утворення термінів є: синтаксичний (утворення термінологічних словосполучень $\mathrm{i}$ фразових термінів), наприклад: berufliches Gymnasium - професійна гімназія; gymnasiale Oberstufe - гімназія вищого ступеня; морфологосинтаксичний (утворення складних термінів): die Halbjahresleistungen досягнення учнів за семестр; абревіація (утворення абревіатур): Закон «Про професійну освіту» (Berufsbildungsgesetz (BBiG)): Закон «Про сприяння професійному навчанню» (BerBiFG), Положення «Про організацію навчального процесу для професій, що вимагають спеціальної підготовки» (Ausbildungsverordnungen), рік основного професійного навчання (Berufsgrundbildungsjahr (BGJ)).

При морфологічному способі утворення термінів новий термін утворюється 3 кількох основ за допомогою словотворчих афіксів. Афіксація $\epsilon$ класичним й досить продуктивним способом словотворення. Утворення академічних термінів здійснюється за тими самими словотвірними механізмами, що й для слів загальнолітературної мови. У німецькій академічній терміносистемі суфіксально-префіксальна деривація є досить розповсюдженим явищем. 
Префіксальний тип словотворення представлений у німецькій мові значно ширше, ніж в українській. Продуктивними $є$ дієслівні префікси, що знаходяться у складі основ іменників, утворених від основ відповідних дієслів: aus-: der Ausbildungsmonitor - навчальний монітор, der Auszubildende - учень; ab-: die Abschlussklasse - останній клас, die Abschlussprüfung - останній іспит; Weiter-: die Weiterbildung підвищення кваліфікації; vor-: Vorphysikum - іспити (медична, ветеринарна освіта); die Vorklasse - підготовчий клас; das Vorprüfungszeugnis - свідоцтво про залік; der Vorkurs - підготовчий курс; die Vorlesung - лекція, Vorpraktikum - попередня практика; zu-: der Zugang - допуск (до іспиту або заліку); die Zwischenprüfung - залік.

Широке застосування в утворенні академічних термінів німецької мови знаходить наразі суфіксація. Семантичний тип позначення осіб, зайнятих певним родом занять в освіті у німецькій мові, представлений наступними суфіксальними моделями словотворення:

1. R + er: der Gymnasiallehrer - вчитель гімназіï, der Kultusminister міністр культури, der Doktorvater - науковий керівник дисертанта, der Dolmetscher - перекладач, der Gelehrte - вчений, der Ausbildungsbotschafter - працівник освіти, der Ausbildungsleiter керівник, der Schulabgänger - випусник. Крім того, модель $\mathrm{R}+$ er $\epsilon$ суфіксальним способом утворення вищеназваного семантичного типу, яка в сучасній німецькій мові є надзвичайно продуктивною і презентує терміни, що називають осіб за родом діяльності або соціальним станом. 2. R + ler: der Zehntklässler - учень 10-го класу.3. R + ist: der Specialist спеціаліст.4. R + or: der Rektor - ректор, der Professor - професоp, der Lektor - лектор, der Direktor - директор, der Doktor - доктор, der Inspektor - інспектор. 5. R + ent : der Dozent - доцент; der Assistent - асистент; der Abiturient - абітурієнт. 6. R + ast: der Gymnasiast - гімназист.7. R + e: der Hauptfachkollege - колега $з$ основного фаху; der Ausbildungsexperte експерт освітньої галузі.8. R + ant: der Aspirant - аспірант. 9. R + antin: die Aspirantin - аспірантка.10. R + de: der Auszubildende - учень. 11. $\mathrm{R}+$ te: die Beauftragte für Berufs- und Studienorientierung - уповноважена у справах професійного навчання. 12. Іменники, утворені 3 дієслівних основ: der Sitzenbleiber - особа, яка залишається на другий рік у школі.

Семантичний тип позначення академічних процессів у німецькій мові представлений наступними суфіксальними моделями словотворення: 1. R + ung: die Modularisierung - модуляризація, die Modernisierung модернізація, die Zertifizierung - сертифікація, die Fächerspezialisierung фахова спеціалізація. 2. R + tion: die Habilitation - габілітація, die Promotion - захист докторської дисертації, die Dissertation - докторська 
дисертація, die Exmatrikulation - відрахування, die Immatrikulation зарахування, die Motivation - мотивація. 3. $\mathrm{R}+$ enz: die Basiskompetenz базова компетенція, die Kultusministerkonferenz - Постійна конференція міністрів культури федеральних земель. 4. R + tät: die Fakultät факультет, die Universität - університет. 5. $\mathrm{R}+$ schaft: die Schülerschaft школярство. 6. R + ieren: studieren - навчатися в університеті, promovieren - захищати дисертацію.

Проблема розумного співвіднесення запозичених $\mathrm{i}$ вітчизняних понять і термінів академічної освіти розглядається наразі набагато глибше, ніж похибки у механічному перекладі української термінології на іноземну мову. Тому в умовах активної міжнародної співпраці університетів особливої актуальності набуває необхідність їх адекватного і правильного перекладу.

\section{Література:}

1. Дресслер Б. Формирование и эволюция терминологии предметной области «Высшее и послевузовское профессиональное образование»: когнитивно-деривационный и социокультурный аспекты: на материале русского и немецкого языков. (Дис. ... док. фил. наук). Кубанский государственный университет, Краснодар, 2011.

2. Мечковская Н. Б. Общее языкознание: Структурная и социальная типология языков. Флинта: Наука, 2001.

3. Пономаренко Е. В. Английский дискурс в свете функциональной лингвосинергетики. Филологические науки, № 5. 2006. С. 100-110.

4. Самиев 3. К. Лингвистический анализ терминологии отрасли образования. (Дис. ... канд. фил. наук). Таджикский национальный университет. Душанбе, 2014.

5. Тузлукова В. И. Международная педагогическая терминология: теория, практика, перспективы. (Дис. ... док. фил. наук). Ростовский Государственный педагогический Университет. Ростов-на-Дону. 2002. 